\title{
Performance Analysis of Three Phase Induction Motor based on ATV12HU15M2 Inverter for Control System Practicum Module
}

\author{
$1^{\text {st }}$ Chico Hermanu Brillianto Apribowo \\ Department of Electrical Engineering \\ Universitas Sebelas Maret \\ Surakarta, Indonesia \\ chico@ft.uns.ac.id
}

\author{
$2^{\text {nd }}$ Mohammad Hakim Adhiguna \\ Department of Electrical Engineering \\ Universitas Sebelas Maret \\ Surakarta, Indonesia \\ adhigunamh@student.uns.ac.id
}

\author{
$3^{\text {rd }}$ Feri Adriyanto \\ Department of Electrical Engineering \\ Universitas Sebelas Maret \\ Surakarta, Indonesia \\ feri.adriyanto@staff.uns.ac.id \\ $4^{\text {th }}$ Hari Maghfiroh \\ Department of Electrical Engineering \\ Universitas Sebelas Maret \\ Surakarta, Indonesia \\ hari.maghfiroh@staff.uns.ac.id
}

\begin{abstract}
Understanding that electrical engineering graduates who have experience and are able to know the electric power system in the industry are the main thoughts of the writer to conduct research. Through the manufacture of a three-phase ac motor control practicum module, which is the type of motor most often used in industrial activities, is expected to provide more knowledge to prospective graduates of electrical engineering engineers. The author determines the two previous research categories chosen as references, namely the training of electric motor modules and the final project of electrical engineering students. In this study the ATV12HU15M2 inverter is used to control changing the frequency value as an input variable to determine its effect on output variables such as voltage, current, power, rpm, and THD. Equipped with SoMove software that is connected to the laptop to be able to change the value of input variables such as motor power, number of poles, and power factors to match the specifications of the electric motor used, the software can also monitor if an error occurs in the system. At the measurement stage, the measuring instrument used is a Power Analyzer to measure the input power of a single-phase system at the source grid PLN, the output power of a three-phase electric motor system, and experimental measurements of motors coupled with a de generator. For the purposes of data processing, DataView software is used to display the measurement results into a laptop, the resulting display can be in the form of a waveform graph, a graph of THD occurrence, and power information for which the displayed data can be stored. The THD result most optimal at $50 \mathrm{~Hz}$ frequency with $\mathrm{THDv}$ value $18.69 \%$ and THDi value $9.04 \%$.
\end{abstract}

Keywords-measurement, monitoring, three phase ac motor, ATV12HU15M2 inverter

\section{INTRODUCTION}

Until now, a number of universities still get complaints from industry about the extent of the capabilities of technical graduates when starting certain jobs. Most questioned about the inability of engineering graduates to be able to adapt to the industrial environment. Even worse, there are skills mismatches during the industrial training period that workers have. Occurs because industrial training materials are not relevant to what workers learn in college. This is the responsibility of the university to be able to provide significant and useful industrial training for its students.

In the implementation of practicum in a laboratory, a module which has been integrated is needed so that students can more easily understand and master electricity skills comprehensively. One of the modules that is most needed by the Laboratory of Energy Conversion and Electric Power Systems in an effort to provide industrial application practices is the induction electric motor module. An electric motor module consists of an electric motor driver, control panel and monitoring equipment as well as an induction motor load.

\section{METHODS}

The inverter is equipped with SoMove Software as a driver set up. Power Analyzer Measurement Tool as a measurement of research. Storage of measurement data using DataView Software. The method begins with making a three-phase AC motor control circuit. After that, controlling the frequency variable values. Then the next step is to measure and process data to the computer.

\section{A. Induction Motor}

Induction motor works based on the electromagnetic induction that occurs in the stator coil to the rotor coil. Flux is induced from the stator coil will cut the rotor coil resulting in electromotive force (emf) or called an induced voltage. The induction works based on the electromagnetic induction that occurs in the stator coil to the rotor coil.

Induction motor rotation speed can be determined by the equation:

$$
n_{s}=\frac{120 * f}{P}
$$

which means, the synchronous speed (Ns) adjustment of an induction motor can be done by adjusting the frequency (f) of alternating sources, while changing the number of motor poles $(\mathrm{P})$ is considered impractical. 


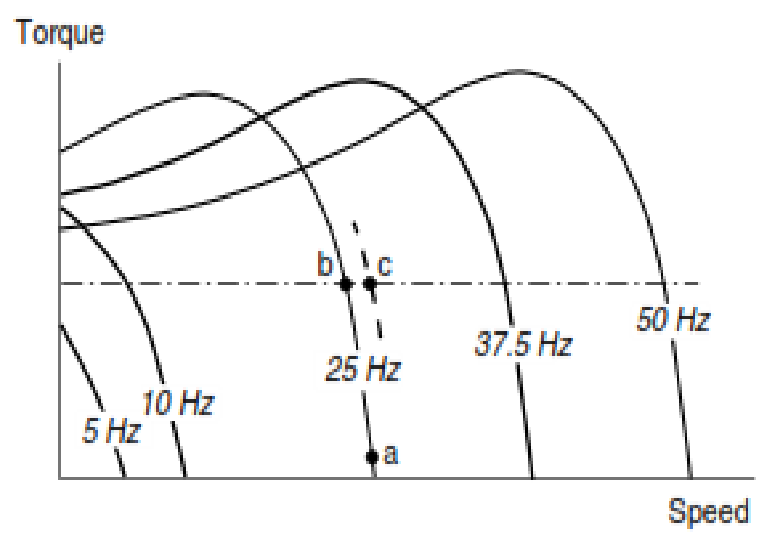

Fig 1. Graph of the influence of frequency on speed

The basic difference between synchronous and asynchronous motors is the asynchronous motor slip occurs. Where slip is the occurrence of differences in the value of rotation on the stator and the value of rotation on the rotor.

$$
S=\frac{n_{s}-n_{r}}{n_{s}}
$$

to make a synchronous motor, the stator speed value is the same as the rotor speed value. Therefore $100 \%$ compensation slip is used to meet the equation, so that a slip of zero can be obtained.

\section{B. Single Phase and Triple Phase Power}

Single phase power measurement is performed on grid power input from PLN

\section{Active power $(\mathrm{P})$ single phase $=\mathrm{V} I \cos \varphi$}

Three-phase power measurements are carried out at the output power output of the electric motor

$$
\text { Active power }(\mathrm{P}) \text { three phases }=\sqrt{ } 3 \mathrm{~V} \mathrm{I} \cos \varphi
$$

Not all electric power absorbed by an induction motor turns into mechanical power, some of it is lost in the form of thermal power. Efficiency value is a function of the ratio of mechanical power to electric power.

$$
\text { efficiency } \%=\frac{\text { three }- \text { phase output power }}{\text { single }- \text { phase output power }} \times 100 \%
$$

C. AC Driver

AC Driver Components consist of:

1) Converter circuit from $\mathrm{AC}$ to $\mathrm{DC}$

2) DC Wave Filter

3) Inverter circuit from $\mathrm{DC}$ to $\mathrm{AC}$.

The existence of this circuit causes harmonic distortion due to the influence of the electronic components.

Total Harmonic Distortion of the voltage used equation:

$$
T H D_{V}=\frac{\sqrt{V_{1}^{2}+V_{2}^{2}+V_{3}^{2}+\cdots+V_{n}^{2}}}{V_{1}}
$$

Total Harmonic Distortion of the current used equation:

$$
T H D_{1}=\frac{\sqrt{I_{1}^{2}+I_{2}^{2}+I_{3}^{2}+\cdots+I_{n}^{2}}}{I_{1}}
$$

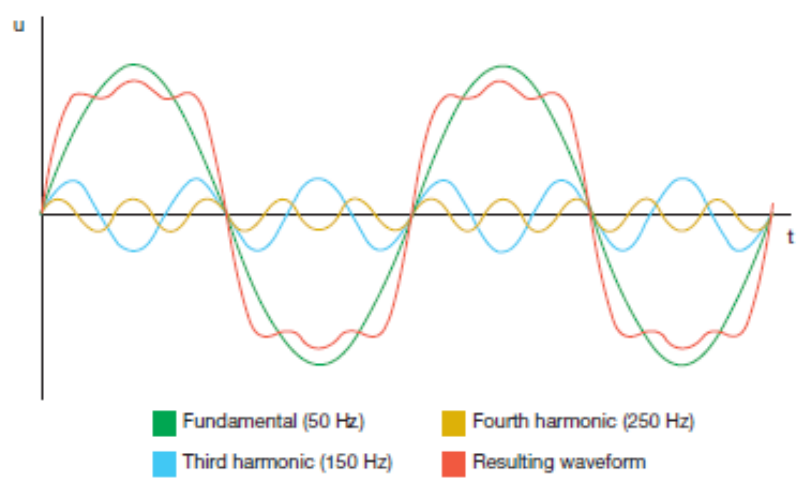

Fig 2. Total Harmonic Distortion

Displacement power factor (DPF) is the ratio between active power (W) to pseudo power (VA) in the base wave. While the power factor is the ratio between active power and apparent power on composite waves including inductive effects by harmonic components.

Power factor $=\cos \varphi$

$$
\begin{gathered}
\text { power factor }=\frac{\text { active power (watt) }}{\text { apparent power }(V A)} \\
P F=\frac{1}{\sqrt{1+T H D^{2}}} \times D P F
\end{gathered}
$$

The DPF value will be the same as the PF if in the sinusoidial V and I linear circuits.

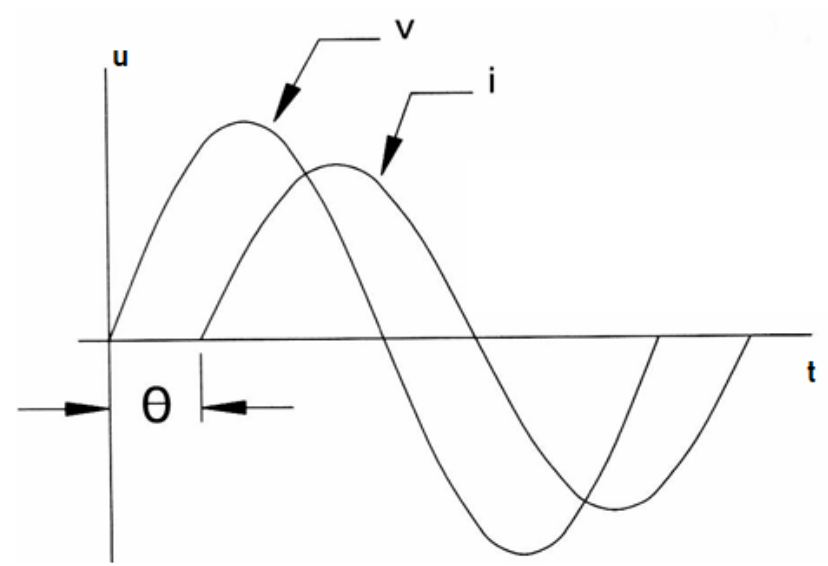

Fig 3. Sinusoidal wave graphs of linear circuits $v$ and $i$ 


\section{Research Methods}
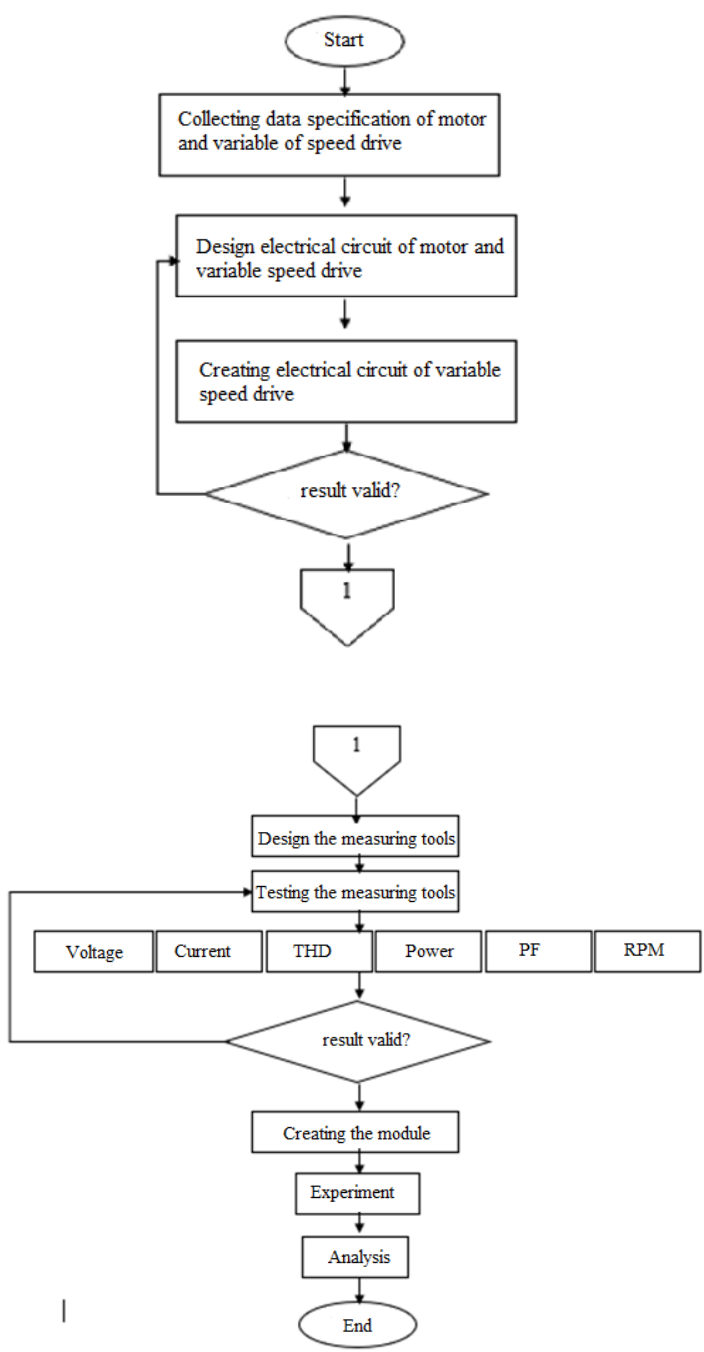

E. Specifications of Induction Motors

Table 1. Specification of three-phase induction Motor

\begin{tabular}{|l|l|l|l|l|l|l|l|}
\hline $\begin{array}{l}\text { Motor } \\
\text { Series }\end{array}$ & \multicolumn{2}{|c|}{ Output } & \multirow{2}{*}{ (V) } & (A) & (rpm) & (\%) & PF \\
\cline { 2 - 8 } & HP & KW & & & & \\
\hline Y2-8012 & 1 & 0.75 & 380 & 1.8 & 2825 & 75 & 0.83 \\
\hline
\end{tabular}

\section{F. Setting Input Parameter}

Table 2. Setting Input Parameter

\begin{tabular}{|c|c|}
\hline Frequency Value & Condition \\
\hline 18.3 & I \\
\hline 26.225 & II \\
\hline 34.15 & III \\
\hline 42.075 & IV \\
\hline 50 & V \\
\hline
\end{tabular}

G. Configurations of Measuring Tools

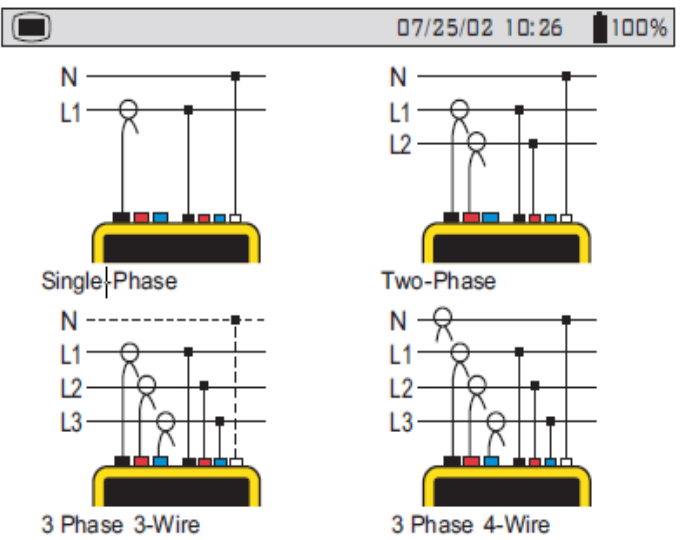

Picture 1. Wiring Configurations

\section{H. Data Storage}

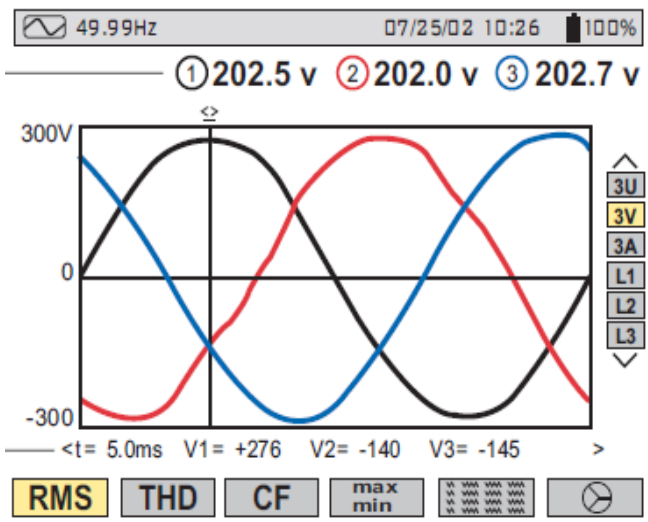

Picture 2. Data Storage

\section{RESULTS AND ANALYSIS}

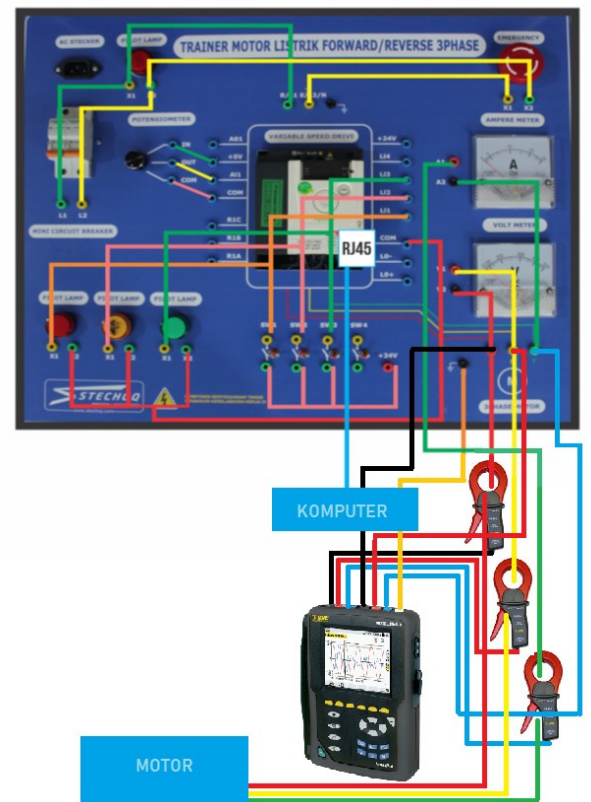

Picture 3. Illustrations of Measurement 
1. Single Phase Condition
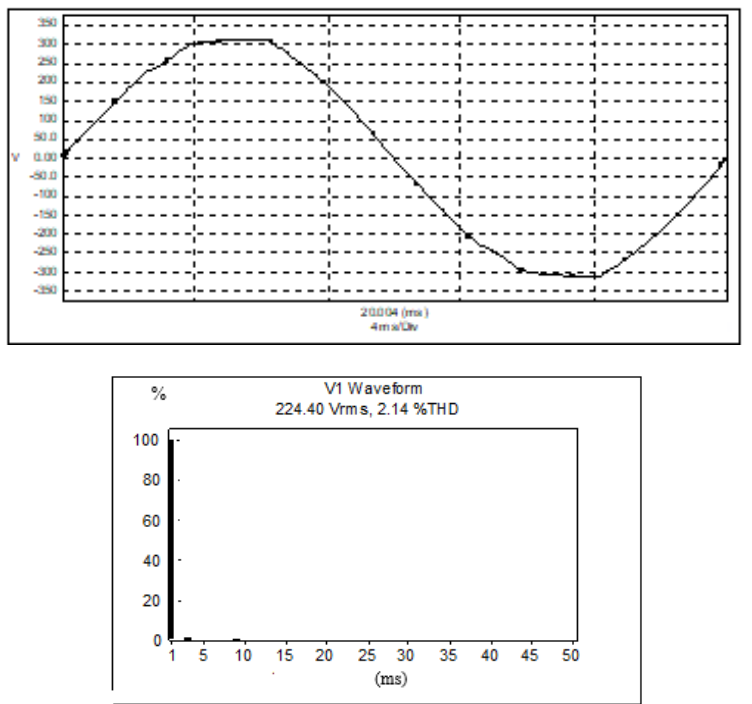

Picture 4. Voltage Graphic on Single Phase
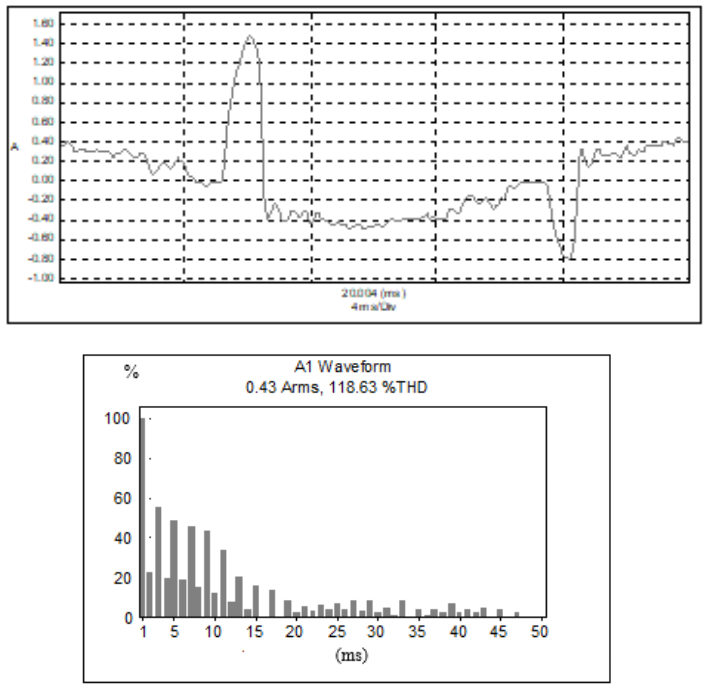

Picture 5. Current Graphic on Single Phase

In the condition of the PLN input grid voltage THD values tend to be stable. The THD value of a fluctuating current is possible because the current value is not large enough.

\begin{tabular}{|l|l|l|l|l|}
\hline $\begin{array}{c}\text { Frequency } \\
(\mathbf{H z})\end{array}$ & $\begin{array}{c}\text { Voltage } \\
\text { (Vrms) }\end{array}$ & $\begin{array}{c}\text { THDV } \\
(\mathbf{\%})\end{array}$ & $\begin{array}{c}\text { Current } \\
\text { (Arms) }\end{array}$ & $\begin{array}{c}\text { TDHI } \\
(\%)\end{array}$ \\
\hline 18.3 & 224.4 & 2.14 & 0.43 & 118.63 \\
\hline 26.225 & 224.51 & 2.25 & 0.61 & 157.8 \\
\hline 34.15 & 225.03 & 2.21 & 0.57 & 147.13 \\
\hline 42.075 & 224.85 & 2.18 & 0.71 & 160.99 \\
\hline 50 & 224.64 & 2.26 & 0.75 & 153.87 \\
\hline
\end{tabular}

2. Three Phase Condition
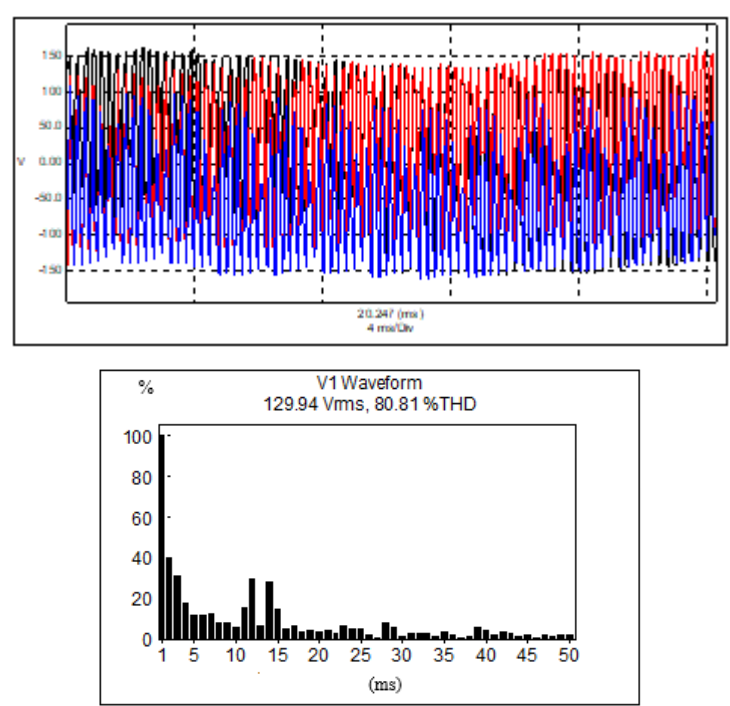

Picture 6. Voltage Graphic on Three Phase
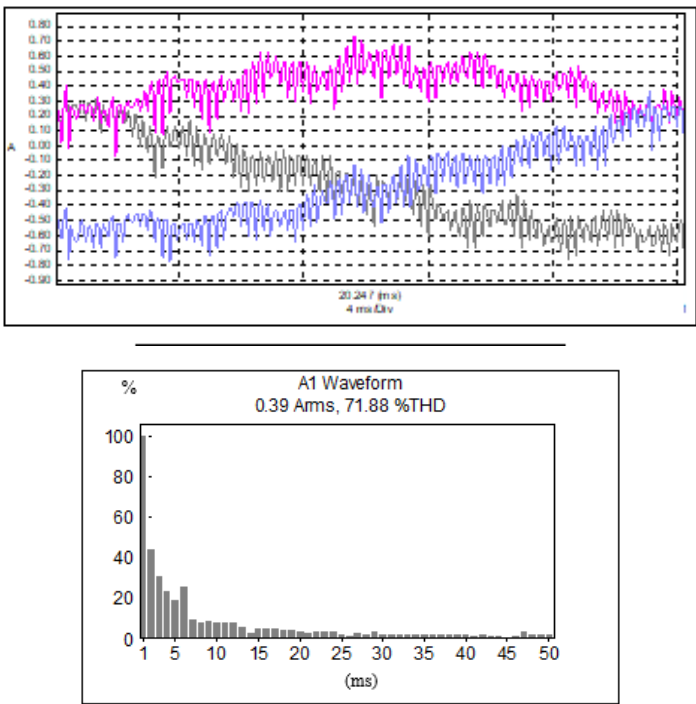

Picture 7. Current Graphic on Three Phase

In the module power output condition, voltage and current THD values experience decrease. At the $50 \mathrm{~Hz}$ frequency the most optimal conditions are due to the smallest voltage and current THD values.

\begin{tabular}{|l|l|l|l|l|}
\hline $\begin{array}{c}\text { Frequency } \\
(\mathbf{H z})\end{array}$ & $\begin{array}{c}\text { Voltage } \\
\text { (Vrms) }\end{array}$ & $\begin{array}{c}\text { THDV } \\
\mathbf{( \% )}\end{array}$ & $\begin{array}{c}\text { Current } \\
\text { (Arms) }\end{array}$ & $\begin{array}{c}\text { TDHI } \\
(\%)\end{array}$ \\
\hline 18.3 & 129.94 & 80.81 & 0.39 & 71.88 \\
\hline 26.225 & 137.35 & 60.58 & 0.38 & 30.72 \\
\hline 34.15 & 139.27 & 45.79 & 0.38 & 33.62 \\
\hline 42.075 & 139.55 & 20.4 & 0.41 & 10.48 \\
\hline 50 & 139.88 & 18.69 & 0.4 & 9.04 \\
\hline
\end{tabular}




\section{B. The Effects of Frequency to Power Value}

In the state of the PLN input grid, the value of the power has increased the value of the power factor used is constant. While the voltage value tends to be stable, the current value increases.

\begin{tabular}{|c|c|c|c|}
\hline $\begin{array}{c}\text { Frequency } \\
\text { (Hz) }\end{array}$ & $\begin{array}{c}\text { Voltage } \\
\text { (Vrms) }\end{array}$ & $\begin{array}{c}\text { Current } \\
\text { (Arms) }\end{array}$ & $\begin{array}{c}\text { Power } \\
\text { (KW) }\end{array}$ \\
\hline 18.3 & 129.94 & 0.39 & 0.075 \\
\hline 26.225 & 137.35 & 0.38 & 0.077 \\
\hline 34.15 & 139.27 & 0.38 & 0.078 \\
\hline 42.075 & 139.55 & 0.41 & 0.084 \\
\hline 50 & 139.88 & 0.40 & 0.082 \\
\hline
\end{tabular}

In the module output condition, the voltage and current values tend to be stable. Power values tend to be stable.

\begin{tabular}{|c|c|c|c|}
\hline $\begin{array}{c}\text { Frequency } \\
\text { (Hz) }\end{array}$ & $\begin{array}{c}\text { Voltage } \\
\text { (Vrms) }\end{array}$ & $\begin{array}{c}\text { Current } \\
\text { (Arms) }\end{array}$ & $\begin{array}{c}\text { Power } \\
\text { (KW) }\end{array}$ \\
\hline 18.3 & 224.4 & 0.43 & 0.082 \\
\hline 26.225 & 224.51 & 0.61 & 0.116 \\
\hline 34.15 & 225.03 & 0.57 & 0.109 \\
\hline 42.075 & 224.85 & 0.71 & 0.136 \\
\hline 50 & 224.64 & 0.75 & 0.143 \\
\hline
\end{tabular}

\section{The Effects of Frequency to Efficiency Value}

The value of frequency has increased as efficiency goes decreased. The effect of frequency changes directly proportional to changes in efficiency.

\begin{tabular}{|c|c|c|c|}
\hline $\begin{array}{c}\text { Frequency } \\
\text { (Hz) }\end{array}$ & $\begin{array}{c}\text { Output } \\
\text { Power } \\
\text { (KW) }\end{array}$ & $\begin{array}{c}\text { Input } \\
\text { Power } \\
(\text { KW) }\end{array}$ & $\begin{array}{c}\text { Efficiency } \\
(\%)\end{array}$ \\
\hline 18.3 & 0.075 & 0.082 & 90 \\
\hline 26.225 & 0.077 & 0.116 & 70 \\
\hline 34.15 & 0.078 & 0.109 & 70 \\
\hline 42.075 & 0.084 & 0.136 & 60 \\
\hline 50 & 0.082 & 0.143 & 60 \\
\hline
\end{tabular}

\section{CONCLUSION}

Further research can be done on the measurement of loading experiments, which in this study, the output value of the loading of a DC generator is not valid enough, because the AC motor coupling to the asynchronous DC generator causes the motor to not be able to spin as it should to reach the specified conditions. Current values below 0.5A cannot be read precisely, to minimize fluctuations in current data readings, it requires setting clamp with a smaller range.

\section{ACKNOWLEDGMENT}

The authors would like to thank the Laboratory Assistants Team in Electrical Engineering, Faculty of Engineering Universitas Sebelas Maret for this project.

\section{REFERENCES}

[1] ECSIP Consortium, "Study on the Competitiveness of the Electrical and Electronic Engineering Industry Final Report,” 2013.

[2] Peraturan Presiden Republik Indonesia, "Masterplan Percepatan Dan Perluasan Pembangunan Ekonomi Indonesia 2011 - 2025," Jakarta, 2014.

[3] I. W. Djatmiko, "Modul Pelatihan Aplikasi Elektronika Daya Untuk Pengaturan Motor Induksi Bagi Para Guru SMK di Daerah Istimewa Yogyakarta," Yogyakarta, 2013.

[4] A. Putranto, "Kontrol Arah dan Kecepatan Putaran Motor AC 3 Phasa Menggunakan Inverter Altivar 312," Widyaiswara Departemen Elektro - PPPPTK BOE, Malang, 2014.

[5] Nurfaizah M, "Rancang Bangun Modul Praktikum Motor AC Dengan Aplikasi Pengaturan Posisi Dengan Menggunakan PID,” Politenik Negeri Batam, Batam, 2015

[6] M. Hasbi Hazmi B., "Pengukuran Harmonisa Pada Altivar 28HU18M2U Dan 31HD15N4," Universitas Diponegoro, Semarang, 2015.

[7] Harmini, "Pengembangan Sistem Monitoring dan Kontrol Motor AC 3 Phase," Universitas Semarang, Semarang, 2016.

[8] Noorly Evalina, "Pengaturan Kecepatan Putaran Motor Induksi 3 Fasa Menggunakan Programmable Logic Controller," Universitas Muhammadiyah Sumatera Utara, Medan, 2018.

[9] Luthfy Makhmudy, "Perancangan Kompensator Daya Reaktif Variabel Sebagai Alat Penghemat Energi Pada Beban Motor Induksi Satu Fasa 1/4 Hp Dengan Monitoring Berbasis Internet Of Things (IOT)," Universitas Sebelas Maret, Surakarta, 2019. 